Relations industrielles

Industrial Relations

\title{
Vannoy, Dana and Paula J. Dubeck (editors), Challenges for Work and Family in the Twenty-First Century
}

\section{Sylvie St-Onge et Gilles Guérin}

Volume 54, numéro 3, 1999

URI : https://id.erudit.org/iderudit/051261ar

DOI : https://doi.org/10.7202/051261ar

Aller au sommaire du numéro

Éditeur(s)

Département des relations industrielles de l'Université Laval

ISSN

0034-379X (imprimé)

1703-8138 (numérique)

Découvrir la revue

Citer ce compte rendu

St-Onge, S. \& Guérin, G. (1999). Compte rendu de [Vannoy, Dana and Paula J. Dubeck (editors), Challenges for Work and Family in the Twenty-First Century]. Relations industrielles / Industrial Relations, 54(3), 622-624.

https://doi.org/10.7202/051261ar

Tous droits réservés @ C Département des relations industrielles de l'Universite Laval, 1999
Ce document est protégé par la loi sur le droit d'auteur. L’utilisation des services d'Érudit (y compris la reproduction) est assujettie à sa politique d'utilisation que vous pouvez consulter en ligne.

https://apropos.erudit.org/fr/usagers/politique-dutilisation/ 
(petite/grande séries, usage de la maind'œuvre et niveau de technologie utilisée). À cet effet, il nous semble que la fabrication de la pâte comme du papier sont des procédés à flux continu comme la pétrochimie alors que l'industrie plastique est une industrie de grande série, ce qui la rapprocherait de l'industrie textile. Par ailleurs, certains secteurs, tout aussi stratégiques dans l'économie québécoise et par rapport à la transformation des modèles productifs, sont absents de l'échantillon. Nous pensons, par exemple, à des secteurs plus directement identifiés à la nouvelle économie comme l'industrie aéronautique ou l'industrie électronique.

La troisième question est plutôt d'ordre méthodologique. L'opérationnalisation est à plusieurs égards intéressante. Les auteurs ont utilisé plusieurs indicateurs simples qui permettaient de produire un portrait complet des changements possibles dans les différentes dimensions constitutives de l'entreprise. Par contre, il faut noter que comme dans beaucoup d'enquêtes quantitatives réalisées auprès des entreprises, le taux de réponses est faible. Il l'est particulièrement dans certains secteurs $(16,7 \%$ dans les entreprises des matières plastiques et des résines synthétiques, soit quatre entreprises sur vingt-quatre). Le nombre d'entreprises est aussi très faible dans certains secteurs (deux entreprises de la pétrochimie ont répondu). Ces deux facteurs font que les pourcentages et les indices sont, en fait, calculés sur de petits nombres. Cela soulève un problème: celuj du degré de signification des différences notées sur les différents indices entre les secteurs. Or, aucune discussion méthodologique sur cette question n'est présentée dans le texte. Cet aspect, en apparence technique, est quand mème un élément important dans la mesure où il permet de recueillir l'adhésion du lecteur quant au propos général. À cet égard, le manque d'informations techniques a créé à la lecture un malaise persistant ou un doute sur la pertinence des conclusions (l'usage du terme de malaise ou de doute est justifié parce que les auteurs ne fournissent pas les informations minimales sur la construction des indices, soit les modalités de fabrication des indices et les seuils de signification. Il apparaît alors difficile de vraiment juger de leur pertinence). Ce malaise est particulièrement fort quand on compare l'intensité des changements. En effet, en sachant que le déplacement de deux entreprises de la pétrochimie d'une catégorie de réponse à l'autre ferait modifier du tiers le pourcentage, la mesure de comparaison devient particulièrement fragile.

\section{PIERRE DORAY \\ Université du Québec à Montréal}

\section{Challenges for Work and Family in the Twenty-First Century}

edited by Dana VANNOY and Paula J. DUBECK, New York: Aldine De Gruyter, 1998, 234 p., ISBN 0-202-30567-8 (alk. paper) and 0-202-30568-6 (pbk: alk. paper).

This book stems from a November 1996 conference at the Kunz Center for the Study of Work and Family in Cincinnati, Ohio entitled "Agenda for the $21^{\text {st }}$ Century Labor Force". The fourteen chapters are grouped into four themes.

Part 2, Present Realities: Setting the Stage, provides an overview of the current dialogue about the family, work, and their interdependence. In Chapter 2 ,
Kathleen Gerson (New York University) argues that workplace resistance to changing family and gender realities as well as the conservation of structures that assume a "traditional family" create difficult dilemmas for both men and women and for which any solution requires fundamental changes in workplace structures. In Chapter 3, Michael Wallace (Indiana University) considers the implications of changes such as 
corporate downsizing, the growing importance of the contingent labour force, the changing value of a college degree and the "growth" of certain occupations. In Chapter 4, Harriet Presser (University of Maryland) draws on statistical data to highlight how factors such as the growth in the service economy and the aging of the population) increase the demand for non-standard work schedules which may undermine the quality of family life. In Chapter 5, Maxime Baca-Zinn (Michigan State University) presents three progressive perspectives: feminism, political economy and family demography. In each of these perspectives, families are posited to evolve in a racially organized social structure that provides and/or denies opportunities, thereby influencing the way families in different social locations (especially the Latino family) organize themselves to survive.

Part 3, Work and Family Adaptations in a Changing Context, focuses on the complexity of today's society. In Chapter 6, Marilyn Fernandez (Santa Clara University) and Kwang Chung Kim (Western Illinois University) analyse employment and income for minority and white dualearner couples. They argue that a multiracial framework, one which transcends the traditional biracial "black-white" framework, is needed to understand minority family adaptation to the new economy. In Chapter 7, Phyllis $\mathrm{H}$. Raabe (University of New Orleans) investigates part-time managers in the U.S. Federal Civil Service, more precisely the advantages, costs and conditions of success of such a work schedule formula. In Chapter 8, Andrew Perrin (a doctoral student at the University of California) shows that communities which experience corporate downsizings lose "social capital" in terms of community leadership, emotional costs on workers, and the narrowing perceptions of political possibility for change. In Chapter 9, Kerry Daly and Anna Dienhart (University of Guelph) use a qualitative approach to show how a father's involvement with children is a negotiated phenomenon that incorporates internal as well as external constraints on parenting.

Part 4, New Considerations for the Twenty-First Century, explores timely issues for work and family lives. Toby Parcel's (Ohio State University) examination of the 1997 U.S. welfare reform for women, particularly the implications for the transition from welfare to work and for the well-being of children and families, in Chapter 10, leads to recommendations for legislative change. In Chapter 11, George Farkas and colleagues (Texas) analyse the challenge of bringing elementary school students to grade-level reading by third grade. In Chapter 12 , David Maume's study (University of Cincinnati) points to the more limited upward mobility of women managers in traditional female-dominated jobs as compared to those in traditional maledominated jobs. He further observes that women have not benefited from employment in the public sector. In Chapter 13, Lisa Cubbins (University of Cincinnati) demonstrates stable patterns in the differences in employer-paid health insurance for men and women, as well as for whites and for minorities. Judy Singleton (University of Cincinnati) discusses the need to take care of dependent elderly family members in Chapter 14.

In Part 5, Dana Vannoy (University of Cincinnati) concludes the book with a discussion of the challenges facing modern society in its search for new institutional arrangements promoting both good family relationships and high productivity.

Overall, while this book provides a overview of some of the papers presented at the conference, its particular flavour reflects the sociological specialization of most of the contributors. In this sense, the book provides a broad social, global or macro perspective on the relationship between the new world of work and the new family structure. With the exception of a few papers, the perspective is more 
reflective (i.e., description and explanation of the challenges) than managerial or action oriented (i.e., how to manage or to deal with these challenges). As with almost all conference proceedings, there is a high degree of variance in the relevance and the quality of the contributions. Furthermore, as it is not a deep or exhaustive investigation of this subject, but rather set of specific essays on a variety of topics, readers will be more aware of the various challenges with respect to work and family but will not be provided with answers as to how to deal with each of them.

In summary, it is a typical collection expressing various sociological perspec- tives and survey results on a variety of topics related to the new world of work and family life in North America and from a variety of actor perspectives (employees, government, employers, specific identity groups based on race, sex, etc.). The table of contents is therefore essential as readers will choose some articles rather than others based upon their own interests (as well as the continuing relevance of the data).

SYLVIE ST-ONGE École des Hautes Études Commerciales, Montréal GILLES GUÉRIN Université de Montréal

\section{Growth in Disability Benefits: Explanations and Policy Implications \\ edited by Kalman RuPP and David C. STAPLETON, Kalamazoo, Mich.: W.E. Upjohn Institute for Employment Research, 1998, 435 p., ISBN 0880991887 (cloth: alk. paper) and 0880991879 (pbk.: alk. paper).}

This volume features a collection of research and discussion papers from disability policy experts, as well as disability program administrators, presented at a 1995 conference in Washington, D.C. The purpose of the text is to diffuse research findings that seek to explain the unanticipated expansion of two disability program rolls administered by the U.S. federal government's Social Security Administration (SSA): Disability Insurance (DI) and Supplemental Security Income (SSI). A second objective of the book is to understand the policy implications of the growth of these disability programs. Research reported in the volume was carried out during the $1992-95$ period, subsequent to a mandate from Congress to investigate the near-insolvency of federal disability program funds in 1992.

For the benefit of readers less familiar with the U.S., I will briefly review the role of the Social Security Administration. The general mission of this organization is to administer the government-sponsored retirement income program for all Americans. DI was originally conceived as a bridge program for workers who became disabled during the course of their work life, but were too young to retire and were not eligible to receive benefits under other income replacement programs. On the other hand, SSI is means-tested, providing benefits to poor disabled individuals with insufficient work histories to qualify for DI. Low income DI recipients may receive SSI payments concurrently with DI, with many $\mathrm{DI}$ applicants qualifying for SSI during the five month waiting period before they are eligible for DI benefits.

Both DI and SSI have historically accounted for a relatively small portion of the SSA's activities and expenditures. Recent economic and population developments, as well as administrative factors, have increased the importance of both DI and SSI spending, especially since beneficiaries of these programs are also eligible for health care benefits. With the exception of the elderly and the indigenous, most Americans receive medical insurance coverage through their employer. It should be noted that rapidly 